\title{
Graça e liberdade humana em Juan Luis Segundo: contribuições para vivência da liberdade cristã nos dias atuais
}

\author{
Orientadora: Lúcia Pedrosa de Pádua \\ Mestrando: Alexandre Cordeiro Salles \\ Área de Concentração: Teologia Sistemático-Pastoral \\ Linha de Pesquisa: Religião e Modernidade
}

O objetivo desta dissertação é mostrar, em perspectiva teológica e histórica, que o ser humano possui liberdade de escolha diante da oferta salvífica de Deus. Fomos buscar elementos necessários para fundamentar o nosso pensamento sobre a veracidade do livre-arbítrio no período patrístico nos primeiros séculos do cristianismo. Ao abordar esse tema, Juan Luis Segundo nos conduz ao paradoxo do conflito liberdade versus determinismo. O cristianismo, quando teve que interagir com a filosofia grega, com o objetivo de difundir a sua mensagem para o mundo, usando e recriando alguns de seus conceitos da fé cristã, foi obrigado a assumir formas de expressão muitos diferentes das encontradas no universo cultural bíblico. O mundo filosófico e cristão adere ao discurso da liberdade, mas em um plano mais imaginário que real, devido ao funcionamento de um mundo onde tudo acontece por acaso. Em seguida, Segundo nos leva ao coração do problema sobre o tema da relação entre graça e liberdade humana, na passagem da epístola aos Romanos 7,1425 , que consiste no homem dividido e o medo da liberdade, passagem esta que foi palco de controvérsias na história do cristianismo. Segundo não admitia a passividade no ser humano diante de tamanha responsabilidade diante da criação colocada por Deus de tal maneira que, se este não possui liberdade para criar, o mundo inteiro deixa de ter valor aos olhos de Deus e a criação se torna inútil. Segundo enfatiza a importância da atuação dos determinismos que condicionam a vivência humana da liberdade, contudo, veremos que os determinismos abrem espaço para a possibilidade da liberdade, para mostrar que os determinismos não somente limitam, mas são via e a condição de 
possibilidade da própria liberdade. Outro dado importante foi a negação do livre-arbítrio no período da Reforma Protestante, o que gerou consequências drásticas para a exegese posterior, pois, quando se nega a liberdade do homem diante do convite divino da salvação, toda a responsabilidade da salvação recai em Deus.

Por isso, na evangelização atual, faz-se necessário esclarecer a insuficiência das interpretações realizadas no período da Reforma, fazendo uma crítica ao contexto teológico da Reforma. Atualmente, na evangelização, encontramos a mentalidade de modo de limitar a liberdade humana, o que, para Juan Luis Segundo, continua sendo o grande inimigo da fé cristã nos dias atuais. Ainda hoje, muitos cristãos fazem uma leitura da Palavra de Deus, consciente ou inconscientemente, dado que respiram essa filosofia grega dos determinismos.

Palavras-chave: Graça. Liberdade. Livre-arbítrio. 